\title{
Use of nanofiltration and reverse osmosis in reclaiming micro filtered biologically treated sewage effluent for irrigation
}

Sukanyah Shanmuganathan, Saravanamuthu Vigneswaran ${ }^{*}$, Tien Vinh Nguyen, Paripurnanda Loganathan, Jaya Kandasamy

Faculty of Engineering, University of Technology Sydney (UTS), P.O. Box 123, Broadway, NSW 2007, Australia

*Corresponding author: s.vigneswaran@uts.edu.au, Tel.: 6129514 2641; Fax: 6129514 2633

\section{Highlights}

- Nanofiltration (NF) pre-treatment reduced reverse osmosis (RO) membrane fouling

- Permeates blends of RO after NF treatment and NF only are suitable for irrigation

- $\quad$ NF or RO, alone removed most pharmaceuticals and personnel care products (PPCPs)

- PPCPs removals by NF membranes were lower than those by RO membranes

\begin{abstract}
Micro filtered, biologically treated sewage effluent (BTSE) generally has high sodium adsorption ratio (SAR) and sodium (Na) and chloride (Cl) concentrations. Therefore it cannot be directly used for irrigating sensitive crops. A study was conducted on a micro filtered BTSE from a Sydney water treatment plant to determine whether the BTSE can be treated using nanofiltration (NF) and reverse osmosis (RO) to bring these risk parameters within
\end{abstract}


safety limits. The study showed that using NF and RO alone could not produce the required ratio of SAR. Furthermore, NF alone did not remove the necessary levels of $\mathrm{Na}$ and $\mathrm{Cl}$ ions while RO did. However, blending equal proportions of NF permeate and RO permeate obtained from a two stages hybrid treatment system consisting of NF followed by RO resulted in a product quality suitable for irrigation in terms of the above mentioned risk factors. Utilizing NF prior to RO reduced the RO membrane fouling as well. Both NF and RO removed most of the pharmaceutical and personal care products from the feed water and this may subsequently protect soil and ground water from potential hazards.

Keywords: Irrigation; Nanofiltration; Reverse osmosis; Sodium adsorption ratio; Pharmaceuticals and personal care products

\section{Introduction}

Reclaimed wastewater for irrigation serves as an economical water resource in many countries [1]. It also has several benefits in improving soil health and reducing the need to use fertilisers. However, excessive salts, pathogens, trace organics, sodium (Na) and chloride (Cl) can cause dangerous environmental risks. The water quality criteria for irrigation are mainly characterized in terms of salinity and $\mathrm{Na}$ hazards, $\mathrm{pH}$, and concentrations of some specific ions such as $\mathrm{Cl}^{-}$, borate $\left(\mathrm{BO}_{3}{ }^{3-}\right)$, and nitrate $\left(\mathrm{NO}_{3}{ }^{-}\right)$.

Salinity is a hazard that results from high salt content in the water which directly affects plant growth, crop performance and soil properties [2] and it can be expressed by electrical conductivity (EC). High EC may cause physiological drought in plants. Sodium hazard is measured by sodium adsorption ratio (SAR) which provides the relative concentration of $\mathrm{Na}$ to calcium (Ca) and magnesium (Mg) ions. An excessive level of $\mathrm{Na}$ in 
relation to $\mathrm{Ca}$ and $\mathrm{Mg}$ affects the permeability characteristics of soil profile by changing the soil structure [3]. In addition to these, some specific ions such as $\mathrm{Cl}^{-}, \mathrm{BO}_{3}{ }^{3-}$ and $\mathrm{NO}_{3}{ }^{-}$at excessive levels can severely damage plant growth.

According to Ayers and Westcot [4] an excess concentration of $\mathrm{Cl}^{-}$in soil solution causes this element to accumulate in plant leaves and cause leaf burn/dead leaves. This eventually results in necrosis (dead tissue). While boron (B) is an essential element for plant growth the high concentration of this element causes older leaves to turn yellow and this ultimately causes chlorosis. Nitrogen $(\mathrm{N})$ is also an important element but its over-supply may over-stimulate plant growth, leading to delayed maturity of produce and ultimately its poor quality. As such, nutrient balanced irrigation water is essential in order to have a positive impact on plant growth. According to the water quality standards reported by ANZECC [3], the allowable safety limits of SAR, $\mathrm{Cl}$, Na and $\mathrm{B}$ are $2-8,<175 \mathrm{mg} / \mathrm{L},<115 \mathrm{mg} / \mathrm{L}$, and $<0.5$ $\mathrm{mg} / \mathrm{L}$ for very sensitive crops. The desirable range of $\mathrm{pH}$ for irrigation water is 6.5 to 7.6. The $\mathrm{pH}$ beyond this range (due to bicarbonates and carbonates) causes $\mathrm{Ca}^{2+}$ and $\mathrm{Mg}^{2+}$ ions to form insoluble precipitates and consequently $\mathrm{Na}^{+}$ions become dominant.

However, these standards may vary depending on the sensitivity of crops, SAR and EC of the water, and soil type. Besides these inorganic constituents, pharmaceuticals and personal care products (PPCPs) in irrigation water are increasingly accumulating in crop tissues and this has important implications for people’s health upon consumption. PPCPs are contaminants that have the properties of toxic biological hazards even at low concentrations. Carter et al. [5] reported the accumulation of some pharmaceuticals in the tissues of radish (Raphanus sativus) and ryegrass (Lolium perenne). Another study reported the presence of pharmaceutical residues in plants tissues (especially for alfalfa and apple) which were irrigated by reclaimed water containing pharmaceuticals [6]. The long-term use of irrigation water containing PPCPs may eventually lead to potential groundwater contamination. The 
occurrence of PPCPs in groundwater has been documented in some studies over the last decade [7, 8, 9]. However, the critical toxic values for most of the PPCPs have not been reported in the literature.

Membrane technologies play a key role in reclaiming micro filtered biologically treated sewage effluent (BTSE) and have received much attention during the past few decades owing to the need to overcome water shortage problems [10]. Studies have mainly investigated combining membrane filtration (MF) and ultrafiltration (UF) with RO membranes to remove suspended particles as well as to reduce salinity levels $[11,12]$. Bunani et al. [2] used RO technology to treat biologically treated sewage effluent (BTSE) for irrigation and suggested blending $20-30 \%$ of BTSE and $80-70 \%$ of RO permeate to make product water suitable for irrigation. However, it is not economical to blend high volumes of RO. Mrayed et al. [13] reported a combination of NF and RO treatment processes to treat BTSE and recommended a blending of NF concentrate and RO permeate for irrigation. The reason for this particular blending was to enrich the product water with divalent nutrients as well as to reduce monovalent nutrients in the product water because NF has the ability to reject divalent ions. Conversely, RO can reject both monovalent and divalent ions [14]. They suggested blending NF concentrate and RO permeate at the ratio of 32:68 which resulted in a SAR of 8.2 but this resulted in a high concentration of $\mathrm{Na}$ ions $(588 \mathrm{mg} / \mathrm{L})$ which is not suitable for Na sensitive crops.

None of the above studies have investigated the removal of PPCPs along with inorganics from BTSE water for irrigation use. The objective of this study was to evaluate combining NF and RO (a two stages hybrid system) to raise the quality of micro filtered BTSE water in terms of SAR value and $\mathrm{Na}$ and $\mathrm{Cl}$ concentrations so that it was suitable for irrigation. The possibility of using NF followed by passing part of the NF permeate through RO and combining the NF and RO permeates at suitable ratio to achieve good irrigation water 
quality was tested. The product water's quality was also evaluated for PPCPs to prevent them from poisoning groundwater and soil over the long-term. Furthermore, the layout/configurations of NF and RO membranes were investigated in terms of reducing potential RO membrane fouling.

\section{Materials and Methods}

\subsection{Materials}

\subsubsection{Feed water}

The micro filtered BTSE collected from a water reclamation plant located in Sydney, Australia was used as feed water. Its characteristics and water quality criteria for irrigation use are presented in Table 1. The use of this feed water itself is unsuitable for sensitive crops as the SAR value was 39, and levels of $\mathrm{Na}^{+}$and $\mathrm{Cl}^{-}$were $81-120 \mathrm{mg} / \mathrm{L}$ and 150-300 mg/L, respectively. Therefore the feed water needs to be further treated.

\section{Table 1}

\subsubsection{Membranes}

Three types of NF membranes and an RO membrane were used in this study to compare their effectiveness in removing contaminants of concern. The characteristics of the membranes are presented in Table 2. These three membranes were selected because of their differences in zeta potential or molecular weight cut off (MWCO) value or both, which would help in identifying the mechanisms of DOC, salts and PPCPs removals.

\section{Table 2}

\subsection{Methodology}


A known quantity (20 L) of micro filtered BTSE was filtered through NF or RO membrane (Fig. 1). The NF and RO filtration units (Fig. 1) were equipped with a rectangular cross-flow cell having a membrane area of $68 \mathrm{~cm}^{2}$. The membrane charge has been shown to become less negative (reduced zeta potential) when the temperature of the feed water increased [18]. Therefore, a cooling coil was submerged in the feed water tank to maintain the feed water temperature at a constant $20 \pm 2^{\circ} \mathrm{C}$. A pressure of 4 bar was used for all NF membranes. The clear water fluxes $\left(\mathrm{L} / \mathrm{m}^{2} . \mathrm{h}\right)$ were 55, 12, and 62 for NP 010, NP 030, and NTR 729HF, respectively. Thus the corresponding clear water permeabilities $\left(\mathrm{L} / \mathrm{m}^{2}\right.$. bar.h) were 13.75, 3 and 15.5. The pressure used for RO was 40 bar. The clear water flux was 23.5 $\mathrm{L} / \mathrm{m}^{2} . \mathrm{h}$ and the clear water permeability was $0.59 \mathrm{~L} / \mathrm{m}^{2}$.bar.h. The concentrate (retentate) produced from NF or RO was recirculated back into the feed water. The performance of each membrane was tested using the same operating conditions of the membrane unit. Of the three types of NF membranes the best one was selected for combining with a RO post-treatment.

\section{Fig. 1.}

The direct application of RO leads to RO membrane fouling resulting in reduced life time of RO operation. In order to solve this problem the micro filtered BTSE was passed through NF and the NF permeate served as the feed for RO. This is explained in the schematic diagram in Fig. 2, Treatment train 2. It is assumed here that NF will remove most of the foulants thus preventing them from reaching the RO membrane. This assumption was tested by performing a membrane autopsy for both the RO membranes - one RO membrane which used NF permeate as feed (Fig. 2) and the other one used BTSE directly as feed (Fig. 1) so that the extent of fouling in the two systems can be compared. Another advantage of using NF before RO is that NF may remove most of the PPCPs and this aspect was also tested in this 
study. Even if NF reduces fouling of RO membrane, it cannot satisfactorily remove the toxic monovalent ions, $\mathrm{Na}^{+}$and $\mathrm{Cl}^{-}$. Therefore $\mathrm{RO}$ is required for the removal of these ions. However, RO is more expensive than NF and therefore a blend of RO permeate and NF permeate at suitable proportion is tested to understand whether a satisfactory quality of irrigation water can be produced. This is a cheaper option than using RO alone.

Fig. 2

At the end of the RO operation, a section of the central part of the RO membrane was cut $\left(21.6 \mathrm{~cm}^{2}\right)$ and ultra sonicated for $10-20 \mathrm{~min}$ to extract the membrane depositions into 40 $\mathrm{mL}$ milli-Q water. The dissolved solution was filtered using a filter with $0.1 \mu \mathrm{m}$ opening and analyzed for organic fractions. The details of the analysis have been documented elsewhere [19].

\subsection{Chemical analysis}

Samples of feed water and permeates were collected at different times after the experiments had started depending on the operation time of the membranes. Dissolved organic carbon (DOC) was analyzed using a Multi N/C 2000 TOC Analyser after filtering samples through a filter with a $0.45 \mu$ m opening. Organic fractions were measured on Liquid Chromatography-Organic Carbon Detection (LC-OCD) Model 8 developed by DOC Labor, Dr Huber, Germany. A TSK HW 50-(S) where the column measured the hydrophilic and hydrophobic fractions of organic matter. The analysis of inorganic anions was carried out using a Metrohm ion chromatograph (Model 790 Personal IC) equipped with an auto sampler and conductivity cell detector. Separation was achieved using an A SUPP column 3 (4-150 
$\mathrm{mm})$. Solutions of $\mathrm{Na}_{2} \mathrm{CO}_{3}(3.2 \mathrm{mmol} / \mathrm{L})$ and $\mathrm{NaHCO}_{3}(1.0 \mathrm{mmol} / \mathrm{L})$ were used as mobile phase with a flow rate of $0.7 \mathrm{~mL} / \mathrm{min}$. The details can be found elsewhere [20].

Pharmaceuticals and personal care products were extracted using solid phase extraction (SPE) and analyzed by Liquid Chromatograph with tandem mass spectroscopy. 5 $\mathrm{mL}$ analytes were extracted using $500 \mathrm{mg}$ hydrophilic/lipophilic balance (HLB) cartridges (Waters, Millford, MA, USA). These analytes were separated using an Agilent (Palo Alto, CA, USA) 1200 series high performance liquid chromatography (HPLC) system equipped with a 150 x 4.6 mm, $5 \mu$ m particle size, Luna C18 (2) column (Phenomenex, Torrence, CA, USA). Mass spectrometry was done using an API 4000 triple quadrupole mass spectrometer (Applied Biosystems, Foster City, CA, USA) equipped with a turbo-V ion source employed in both positive and negative electro-spray modes. All calibration curves had a correlation coefficient of 0.99 or better. Details of the analysis are described elsewhere [21].

\section{Results and Discussion}

\subsection{Characterization of feed water}

The suitability of feed water for irrigation was assessed mainly in terms of SAR value, and $\mathrm{Na}$ and $\mathrm{Cl}$ concentrations. In addition, emerging contaminants such as PPCPs were measured to determine whether any potential health hazards to underlying aquifers and soil environments can be caused by irrigation. As the BTSE feed is micro filtered, it can be assumed that bacterial cells/pathogens were removed to a safety level. Moreover, the presence of heavy metals/radioactive substances was not considered because the existence of these contaminants in reclaimed water is negligible [22].

\subsection{Rejection of inorganic solutes and dissolved organics by NF}

The rejection of inorganic solutes by NF is mainly governed by two mechanisms, 
namely electrostatic screening and Donnan effect [23]. As shown in Table 3 the removal of inorganic solutes by NF varied according to the type of NF membrane. The NTR 729HF was more effective than NP 010 and NP 030 in removing inorganic anions because of its significantly higher negative zeta potential $(-100 \mathrm{mV})$ compared to the other two membranes (-12 and $-15 \mathrm{mV})$. Of the anions, this membrane was the most efficient in removing sulphate $\left(\mathrm{SO}_{4}{ }^{2-}\right)$ ions, achieving 99\% of rejection followed by $\mathrm{Cl}^{-}$and $\mathrm{NO}_{3}{ }^{-}$rejections which were $11 \%$ and $<5 \%$, respectively. This agrees with the results obtained by Paugam et al. [24] who reported that inorganic solutes rejection by polyamide NF membranes (same as NTR 729HF) was in the order $\mathrm{SO}_{4}{ }^{2-}>\mathrm{Cl}^{-}>\mathrm{NO}_{3}{ }^{-}$. Paugam et al. [24] explained this order as being due to $\mathrm{SO}_{4}{ }^{2-}$ having higher charge and hydration energy compared to the other two anions. An increase in anion charge leads to greater electrostatic interaction and Donnan effect [14,24] and the more hydrated the ion is the more difficult for its transfer across the membrane [24]. RO was used as a post-treatment because NF is not expected to remove most of the monovalent ions.

The retention of organics by NF during the first $10 \mathrm{~h}$ of operation was efficient and only 0-0.8 $\mathrm{mg} / \mathrm{L}$ of the influent DOC of concentration of $7.5 \mathrm{mg} / \mathrm{L}$ was found in NF permeate which corresponds to a 76-95\% rejection rate (Table 3). NTR 729HF and NP 030 removed a larger percentage of DOC than NP 010 probably because of their lower MWCO, which produced higher physical sieving of the organic molecules [25]. RO with the lowest MWCO removed the largest \%DOC.

\section{Table 3}

The NF permeate concentrations of inorganic solutes and organics increased over time during the operation (Fig. 3). As the concentrate was recirculated back with the feed water, 
the concentration of solutes in the feed water increased over time. This in turn raised the solute concentration in permeate. Past studies have reported a similar phenomenon where the increased salt concentration in the feed water decreased the retention rate of solutes [26, 27]. The reason for this increased concentration in permeate would be due to the membranes adsorption sites reaching saturation at high salt concentrations with less adsorption sites available for further adsorption. Another reason may be due to membrane pore swelling at high salt concentration. According to Escoda et al. [28], an increase in salt concentration produces increased pore size of the membrane (pore swelling) as a result of the higher repulsive forces between counter ions inside the pores which increased membrane charge density.

\section{Fig. 3}

Luo and Wan [29] reported that a high concentration of charged organic electrolytes present in the feed water can also result in a smaller retention of monovalent co-ions by NF. The continuous increase of organics in the feed water observed in this study could be another reason for less inorganic solutes being retained.

The more negatively charged NTR 729HF membrane surface is better able to retain positively charged ions compared to NP 010 and NP 030. In fact the NTR 729HF had higher percentages of rejection of $\mathrm{Na}, \mathrm{Ca}$, and $\mathrm{Mg}$ than the other NFs (Table 3). The rejection percentage was higher for the divalent cations $\mathrm{Ca}$ and $\mathrm{Mg}$ than the monovalent $\mathrm{Na}$ due to higher electrostatic attraction of the ions to the membrane. The membrane rejection capacity exhibited by the NTR 729HF to both monovalent and divalent ions lasted longer than NP 010 and NP 030 (Fig. 3). Thus NTR 729HF was used in the subsequent experiments. However, when comparing the performance of NF membranes with RO in terms of removing 
inorganics, the RO membrane demonstrated an excellent ability to remove both divalent and monovalent ions.

\subsection{Rejection of pharmaceuticals and personal care products}

The rejection of PPCPs by NF and RO membranes is shown in Table 4 where the RO is found to be highly efficient followed by NTR 729HF. The rejections of PPCPs by NP 010 and NP 030 were also significant but considerably less compared to RO and NTR 729HF. When comparing NP 010 and NP 030, the latter had higher rejection for 9 PPCPs and equal rejection for two PPCPs.

Several mechanisms have been proposed to explain the rejection of organics, especially PPCPs, unlike inorganic ions which involve mainly interaction of charges on membranes and inorganic anions. Rejection of PPCP is based on charge interaction of PPCP (pKa values) and membrane, MWCO, and hydrophobicity interactions [25]. Hydrophobicity of PPCPs is measured by $\log \mathrm{P}$ value where $\mathrm{P}$ is defined as the ratio of the concentrations of a solute in octonol to that in water [30]. PPCPs rejections presented in Table 4 are explained using these mechanisms below.

\section{TABLE 4}

The higher PPCP rejection of RO is probably due to the lower MWCO of the RO membrane (100 Da) compared to the molecular weights of PPCPs (194-446 Da) (Table 1) causing steric hindrance [35]. The rejection of PPCPs by steric hindrance cannot be applied to the NF membranes because PPCPs are small organics and all PPCPs except Verapamil (454 Da) investigated in this study were below 400 Da. These are less than the MWCO values of the membranes (400-1000 Da). 
Comparing the performances of NF membranes, the NTR 729HR was observed to be the better performer in rejecting most of the PPCPs despite its higher MWCO (700 Da) compared to the NP 030 (400 Da). Seven PPCPs were significantly rejected by NTR 729HF and detected in permeates below $10 \mathrm{ng} / \mathrm{L}$ in which four were negatively charged (pKa values $<7$ ). The surface of NTR 729HF is more negatively charged (zeta potential $-100 \mathrm{mV}$ at $\mathrm{pH} 7$ ) than the NP 010 and NP 030 (-12 to $-15 \mathrm{mV}$ at $\mathrm{pH}$ 7), thus the electrostatic repulsion forces between the membrane surface and PPCPs may have played a role in the rejection of the negatively charged PPCPs. However, the higher rejection of the positively charged PPCPs such as Veerapamil and Amtriptyline (pKa 8.92 - 9.4) by NTR 729HF may be explained based on their Log $\mathrm{P}$ values (3.79-4.92) in which the rejections were mainly due to hydrophobic interactions. Hydrophobicity is another factor that influences the rejection by NF where generally compounds having high Log P values are highly rejected by the hydrophilic NF membranes [36, 37].

The chemical constitutions of the membranes also influence the rejection capacity of PPCPs. For example, Causserand et al. [38] reported that the retention coefficient of dichloroaniline ranged from $60 \%$ to $95 \%$ with polyamide membranes whilst it was $10 \%$ to $25 \%$ with a cellulose acetate membrane. This is further confirmed by Kiso et al. [39] who noted that the removal of pesticides was significantly higher with NTR 729HF that consisted more of polyamide membranes than polyetersulfone membranes. Polyamide constituent of NTR 729HF could be another reason for the larger rejections of pharmaceuticals observed with NTR 729HF than NP 010 and NP 030 in addition to the higher negative zeta potential of the membrane.

While many studies have examined the removal of micro-pollutants by NF/RO membranes, the mechanisms are still not fully understood due to their complexity [37]. The presence of inferring compounds like natural organics in the water matrix also hinder the 
rejection capacities of some pharmaceuticals. Therefore an in-depth investigation of the membrane and solute properties is needed for a better understanding of the prediction of the rejection capacities.

\subsection{Product water quality evaluation for irrigation}

The NF membranes were effective in removing PPCPs and divalent cations (Ca, Mg). However, when evaluating the product water quality for irrigation, NF permeate alone could not reduce the SAR value below 14 (the safety levels). Furthermore, the $\mathrm{Cl}$ and $\mathrm{Na}$ levels in the NF permeate were $202 \mathrm{mg} / \mathrm{L}$ and $110 \mathrm{mg} / \mathrm{L}$, respectively, which are above the maximum allowable levels for crops sensitive to these elements. The RO process eliminated all the inorganic ions below critical levels; however, it also removed the beneficial ions. As such, it was suggested that blending NF and RO permeate with feed water would be appropriate. In this context, blending $10 \%$ of feed water with $90 \%$ of RO permeate gave an SAR value of 6 ; $\mathrm{Cl}$ concentration of $40 \mathrm{mg} / \mathrm{L}$ and $\mathrm{Na}$ concentration of $15.5 \mathrm{mg} / \mathrm{L}$. In this case the soil infiltration problem can be rectified and the toxicity caused by $\mathrm{Cl}^{-}$and $\mathrm{Na}^{+}$ions is also minimized. However, the use of $90 \%$ of RO permeate is not an economical solution. The blending of NF and RO permeate were found to be a sustainable solution. Blending $50 \%$ of NF permeate and 50\% of RO permeate resulted in a SAR value of 8; $\mathrm{Cl}^{-} 109 \mathrm{mg} / \mathrm{L}$ and $\mathrm{Na}^{+} 57$

mg/L (Table 5). Furthermore, blending feed water instead of NF permeate with RO permeate may still result in high concentrations of PPCPs. Boron and $\mathrm{NO}_{3}{ }^{-}$in the microfiltered BTSE were well within the limits (Table 1).

\subsection{Performance of the nano filtration-reverse osmosis hybrid system}

Membrane autopsy clearly showed that the organic deposition on the RO membrane exposed directly to BTSE was larger than the RO membrane exposed to NF filtered BTSE. 
$\mathrm{NF}$ as a pre-treatment to RO reduced the potential organic foulants on the RO membrane including humics, building blocks and most of the low molecular weight neutrals and acids (Table 3, Fig. 4). Thus blending 50\% of NF and 50\% of RO as per Treatment train 2 would be advantageous in terms of less interrupted RO operation.

The NF flux of NTR 729HF membrane with BTSE decreased from 44 to $42 \mathrm{~L} / \mathrm{m}^{2} . \mathrm{h}$ in $66 \mathrm{~h}$ while NF was operated at 4 bar. The clear water permeability of the used NF and RO membranes were measured at the end of the experiments and they were 14.75 and 0.56 $\mathrm{L} / \mathrm{m}^{2}$.h.bar, respectively. The RO flux decreased from 21.4 to $21.0 \mathrm{~L} / \mathrm{m}^{2} . \mathrm{h}$ in $91 \mathrm{~h}$ while RO was operated at 40 bar with BTSE at similar operation time.

\section{Fig. 4.}

\section{Conclusions}

This study showed that utilizing treated BTSE for irrigation is a viable option for maximizing water reuse in arid and semi-arid regions. Raw micro filtered BTSE is not suitable for irrigation because the SAR value, $\mathrm{Na}^{+}$and $\mathrm{Cl}^{-}$concentrations were higher than the maximum allowable limits for sensitive crops. The blend of either 'raw water - RO permeate' or 'NF permeate - RO permeate after NF pre-treatment' (a two stages system) at the ratios of 10:90 or 50:50, respectively, made the water suitable for irrigation. However, the second option, i.e. blending NF permeate and RO permeate after NF pre-treatment is a cost-effective option as the RO is more expensive than NF and only $50 \%$ of NF permeate was treated by RO. Moreover, in order to ensure RO membrane operates more smoothly with less fouling, the NF process is used as a pre-treatment to RO to achieve partial removal of potential organic foulants. NF removed all the humics, building blocks and most LMW organics. Both 
RO and NF achieved very high removals of PPCPs. This study demonstrated that NF permeate can be blended with permeate of RO after NF pre-treatment in suitable proportions to produce good quality irrigation water. However, the blending proportion of permeates can vary depending on the type of membranes used, soil type, salt tolerance of crops, salts in the soil solution, and wastewater (feed) characteristics.

\section{Acknowledgements}

This study was funded by CRC-CARE. The authors acknowledge Stuart Khan, James McDonald (School of Civil and Environmental Engineering, UNSW) for their help in analysing the PPCPs, and Andrzej Listowski (Sydney Olympic Park Authority, Sydney, Australia) for providing the facility to collect water samples for the experiments.

\section{References}

[1] D. Bixio, T. Wintgens, Water Reuse System Management Manual (AQUAREC), 2006. Directorate-General for Research, Global change and ecosystems.

[2] S. Bunani, E. Yörükoğlu, Ã. Yüksel, N. Kabay, M. Yüksel, G. Sert, Application of reverse osmosis for reuse of secondary treated urban wastewater in agricultural irrigation, Desalination (2014), http://dx.doi.org/10.1016/j.desal.2014.07.030

[3] Australian and New Zealand Environment and Conservation Council (ANZECC), Agriculture and Resource Management Council of Australia and New Zealand, Canberra, ACT, Australia, Australian and New Zealand Guidelines for Fresh and Marine Water Quality, 2000. Primary Industries, volume. 3

[4] R.S. Ayers, D.W. Westcot, Water quality for agriculture. FAO irrigation and drainage paper. FAO of the United States Rome, 1985 (C) FAO ISBN 92-5-102263-1 
[5] L.J. Carter, E. Harris, M. Williams, J.J. Ryan, R.S. Kookana, A.B.A. Boxall, Fate and uptake of pharmaceuticals in soil-plant systems, J. Agric. Food Chem. 62 (2014) 816825.

[6] D. Calderón-Preciadoa, C. Jiménez-Cartagena, V. Matamoros, J.M.Bayona, Screening of 47 organic microcontaminants in agricultural irrigation waters and their soil loading, Water Res. 45 (2011) 221-231.

[7] J.E. Drewes, T. Heberer, T. Rauch, K. Reddersen, Fate of pharmaceuticals during ground water recharge. Ground Water Monit., Remediation 23 (2003) 64-72.

[8] Y. Fang, A. Karnjanapiboonwong, D.A. Chase, J. Wang, A.N. Morse, T.A. Anderson, Occurrence, fate, and persistence of gemfibrozil in water and soil, Environ. Toxicol. Chem. 31 (2012) 550-555.

[9] M.S. Díaz-Cruz, B. Damià, Trace organic chemicals contamination in ground water recharge, Chemosphere 72 (2008) 333-342.

[10] G. Oron, L. Gillerman, A. Bick, N. Buriakovsky. Y. Manor, E. Ben-Yitshak, L. Katz, J. Hagin, A two stage membrane treatment of secondary effluent for unrestricted reuse and sustainable agricultural production, Desalination 187 (2006) 335-345.

[11] R.Y. Ning, T.L. Troyer, Colloidal fouling of RO membranes following MF/UF in the reclamation of municipal wastewater, Desalination 208 (2007) 232-237.

[12] N. Prihasto, Q.F. Liu, S.H. Kim. Pre-treatment strategies for seawater desalination by reverse osmosis system, Desalination 249 (2009) 308-316.

[13] S.M. Mrayed, P. Sanciolo, L. Zou, G. Leslie, An alternative membrane treatment process to produce low-salt and high-nutrient recycled water suitable for irrigation purposes, Desalination 274 (2011) 144-149.

[14] R. Rautenbach, K. Vossenkaul, T. Linn, T. Katz, Waste water treatment by membrane processes - New development in ultrafiltration, nanofiltration and reverse osmosis, 
Desalination 108 (1997) 247-253.

[15] Y. Kaya, Z.B. Gönder, I. Vergili, H. Barlas, The effect of transmembrane pressure and $\mathrm{pH}$ on treatment of paper machine process waters by using a two-step nanofiltration process: Flux decline analysis, Desalination 250 (2010) 150-157.

[16] H.K. Shon, S. Vigneswaran, H.H. Ngo, I.S. Kim, R. Ben Aim, Foulant characterization of the NF membranes with and without pretreatment of biologically treated wastewater, Water Sci. Technol. 51 (2005) 277-284.

[17] H.K. Shon, S. Vigneswaran, M.H. Zareie, R. Ben Aim, E. Lee, J. Lee, J. Cho, I.S. Kim, Physico-chemical pretreatment to seawater reverse osmosis (SWRO): organic characterization and membrane autopsy, Desalination 236 (2009) 282-290.

[18] H. Mo, K.G. Tay, H.Y. Ng, Fouling of reverse osmosis membrane by protein (BSA): Effects of pH, calcium, magnesium, ionic strength and temperature, J. Membr. Sci. 315 (2008) 28-35.

[19] S. Jeong, S.J. Kim, L. Hee Kim, M. Seop Shin, S. Vigneswaran, T.V. Nguyen, I.S. Kim, Foulant analysis of a reverse osmosis membrane used pretreated seawater, J. Membr. Sci. 428 (2013) 434-444.

[20] S. Jeong, S. Vigneswaran. S, Assessment of biological activity in contact flocculation filtration used as a pretreatment in seawater desalination, Chem. Eng. J. 228 (2013) 976983.

[21] V.M. Monsalvo, J.A. Mcdonald, S.J. Khan, P. Le-Clech, Removal of trace organics by anaerobic membrane bioreactors, Water Res. 49 (2014) 103-112.

[22] W. Chen, S. Lu, W. Jiao, M. Wang, A.C. Chang, Reclaimed water: A safe irrigation water source? Environ. dev. 8 (2013) 74-83.

[23] M.R. Teixeira, M.J. Rosa, M. Nyström, The role of membrane charge on nanofiltration performance, J. Membr. Sci. 265 (2005) 160-166. 
[24] L. Paugam, C.K. Diawara, J.P. Schlumpf, P. Jaouen, F. Quéméneur, Transfer of monovalent anions and nitrates especially through nanofiltration membranes in brackish water conditions, Sep. Purif. Technol. 40 (2004) 237-242.

[25] C. Bellona, J.R.E. Drewes, P. Xu, G. Amy, Factors affecting the rejection of organic solutes during NF/RO treatment - a literature review, Water Res. 38 (2004) 2795-2809.

[26] C. Labbez, P. Fievet, A. Szymczyk, A. Vidonne, A. Foissy, J. Pagetti, Analysis of the salt retention of a titania membrane using the "DSPM" concentration and nature, J. Membr. Sci. 208 (2002) 315-329.

[27] C. Mazzoni, L. Bruni, S. Bandini, Nanofiltration: role of the electrolyte and pH on desal DK performances, Indust. Eng. Chem. Res. 46 (2007) 2254-2262

[28] A. Escoda, P. Fievet, S. Lakard, A. Szymczyk, S. Déon, Influence of salts on the rejection of polyethyleneglycol by an NF organic membrane: Pore swelling and saltingout effects, J. Membr. Sci., 347 (2010) 174-182.

[29] J. Luo, Y. Wan, Effects of pH and salt on nanofiltration - a critical review, J. Membr. Sci. 438 (2013) 18-28.

[30] S. Demare, B. Slater, G. Lacombe, D. Breuzin, C. Dini, Accurate automated log P o/w measurement by gradient-flow liquid-liquid partition chromatography: Part 1. Neutral compounds, J. Chromatogr. A. 1175 (2007) 16-23.

[31] E. Hapeshi, A. Achilleos, M.I. Vasquez, C. Michael, N.P. Xekoukoulotakis, D. Mantzavinos, D. Kassinos, Drugs degrading photocatalytically: Kinetics and mechanisms of ofloxacin and atenolol removal on titania suspensions, Water Res. 44 (2010) 1737-1746.

[32] P. Westerhoff, Y. Yoon, S. Snyder, E. Wert, Fate of endocrine-disruptor, pharmaceutical, and personal care product chemicals during simulated drinking water treatment processes, Environ. Sci. Technol. 39 (2005) 6649-6663. 
[33] X. Yang, R.C. Flowers, H.S. Weinberg, P.C. Singer, Occurrence and removal of pharmaceuticals and personal care products (PPCPs) in an advanced wastewater reclamation plant, Water Res. 45 (2011) 5218-5228.

[34] D. Serrano, S. Suárez, J.M. Lema, F. Omil, Removal of persistent pharmaceutical micropollutants from sewage by addition of PAC in a sequential membrane bioreactor, Water Res. 45 (2011) 5323-5333.

[35] E. Sahar, I. David, Y. Gelman, H. Chikurel, A. Aharoni, R. Messalem, A. Brenner, The use of RO to remove emerging micropollutants following CAS/UF or MBR treatment of municipal wastewater, Desalination 273 (2011) 142-147.

[36] Y. Kiso, Y. Sugiura, T. Kitao, K. Nishimura, Effects of hydrophobicity and molecular size on rejection of aromatic pesticides with nanofiltration membranes, J. Membr. Sci. $192(2001) 1-10$

[37] K. Chon, H. Kyongshon, J. Cho, Membrane bioreactor and nanofiltration hybrid system for reclamation of municipal wastewater: Removal of nutrients, organic matter and micropollutants, Bioresour. Technol. 122 (2012) 181-188.

[38] C. Causserand, P. Aimar, J.P. Cravedi, E. Singlande, Dichloroaniline retention by nanofiltration membranes, Water Res. 39 (2005) 1594-1600.

[39] Y. Kiso, Y. Nishimura, T. Kitao, K. Nishimura, Rejection properties of non-phenylic pesticides with nanofiltration membranes, J. Membr. Sci. 171 (2000) 229-237. 
Table 1. Physico-chemical characteristics of feed water

\begin{tabular}{|c|c|c|c|}
\hline Parameter & Unit & $\begin{array}{l}\text { Micro } \\
\text { filtered } \\
\text { BTSE }\end{array}$ & $\begin{array}{l}\text { Australian and New Zealand Guidelines for } \\
\text { Fresh and Marine Water Quality [3] }\end{array}$ \\
\hline $\begin{array}{l}\text { Dissolved organic } \\
\text { carbon (DOC) }\end{array}$ & $\mathrm{mg} / \mathrm{L}$ & $3.6-7.7$ & \\
\hline $\mathrm{pH}$ & - & $6.8-7.6$ & $6.5-8.0$ \\
\hline conductivity & $\mathrm{dS} / \mathrm{cm}$ & $0.52-1.12$ & $\begin{array}{l}<0.65 ; 0.65-2.9 ; 2.9-5.4 ;>8.1 \text { for very } \\
\text { sensitive; sensitive to moderately tolerant; } \\
\text { tolerant to very tolerant; too saline. }\end{array}$ \\
\hline SAR & & 39 & $\begin{array}{l}\text { 2-8; 8-18; 18-146; } 46-102 \text { for very sensitive; } \\
\text { sensitive; moderately tolerant and tolerant } \\
\text { crops. }\end{array}$ \\
\hline $\mathrm{F}^{-}$ & $\mathrm{mg} / \mathrm{L}$ & $0.7-1.1$ & $\begin{array}{l}1.0 \text { and 2.0: long term trigger value and short } \\
\text { term trigger value }\end{array}$ \\
\hline $\mathrm{Cl}^{-}$ & $\mathrm{mg} / \mathrm{L}$ & $150-300$ & $\begin{array}{l}<175 ; 175-350 ; 350-700 ;>700 \text { for very } \\
\text { sensitive; sensitive; moderately tolerant and } \\
\text { tolerant crops }\end{array}$ \\
\hline $\mathrm{NO}_{3}^{-}$ & $\mathrm{mg} \mathrm{N} / \mathrm{L}$ & $1.0-1.3$ & $\begin{array}{l}5 ; 25-125 \text { for long term trigger value and short } \\
\text { term trigger value }\end{array}$ \\
\hline $\mathrm{PO}_{4}{ }^{3-}$ & $\mathrm{mg} \mathrm{P} / \mathrm{L}$ & 0.74-0.99 & $\begin{array}{l}0.05 ; 0.8-10 \text { for long term trigger value and } \\
\text { short term trigger value }\end{array}$ \\
\hline $\mathrm{SO}_{4}{ }^{2-}$ & $\mathrm{mg} \mathrm{S} / \mathrm{L}$ & $49-51$ & \\
\hline $\mathrm{Na}^{+}$ & $\mathrm{mg} / \mathrm{L}$ & $81-120$ & $\begin{array}{l}<115 ; 115-230 ; 230-460 ;>460 \text { for sensitive; } \\
\text { moderately sensitive; moderately tolerant and } \\
\text { tolerant crops. }\end{array}$ \\
\hline $\mathrm{K}^{+}$ & $\mathrm{mg} / \mathrm{L}$ & $15-21$ & \\
\hline $\mathrm{Ca}^{2+}$ & $\mathrm{mg} / \mathrm{L}$ & $21-40$ & \\
\hline $\mathrm{Mg}^{2+}$ & $\mathrm{mg} / \mathrm{L}$ & $10-15$ & \\
\hline $\mathrm{BO}_{3}{ }^{3-}$ & $\mathrm{mg} \mathrm{B/L}$ & $0.04-0.06$ & $\begin{array}{l}<0.5 ; 0.5-2.0 ; 2.0-6.0 ; 6.0-15.0 \text { for sensitive; } \\
\text { moderately sensitive; moderately tolerant and } \\
\text { tolerant crops. }\end{array}$ \\
\hline
\end{tabular}


Table 2. Characteristics of NF and RO membranes

\begin{tabular}{|c|c|c|c|c|c|}
\hline Membrane & Manufacturer & Material & $\begin{array}{l}{ }^{\mathrm{a}} \mathrm{MWCO} \\
\text { (Da) }\end{array}$ & $\begin{array}{l}\text { Membrane } \\
\text { property }\end{array}$ & $\begin{array}{l}\text { Zeta } \\
\text { potential } \\
(\mathrm{mV}) \text { at } \\
\text { pH } 7\end{array}$ \\
\hline NP 010 & Macrodyn ${ }^{\circledR}$ Nadir & Polyetersulfone & 1000 & Hydrophilic & $-12^{b}$ \\
\hline NP 030 & Macrodyn ${ }^{\circledR N a d i r}$ & polyetersulfone & 400 & Hydrophilic & $-15^{\mathrm{b}}$ \\
\hline NTR 729HF & Nitto Denko & $\begin{array}{l}\text { Polyvinylalcoho/poly } \\
\text { amides (Heterocyclic } \\
\text { aromatic) }\end{array}$ & 700 & Hydrophilic & $-100^{c}$ \\
\hline RO & Woongjin Chemical & Polyamides & 100 & - & $-21^{\mathrm{d}}$ \\
\hline
\end{tabular}

${ }^{\mathrm{a}}$ Molecular weight cut off (MWCO)

${ }^{\mathrm{b}}$ Kaya et al [15]

${ }^{\mathrm{c}}$ Shon et al. [16]

${ }^{\mathrm{d}}$ Shon et al. [17] 
Table 3. Rejection (\%) of inorganic solutes and organics by NF/RO membranes during the first 10 hrs operation

\begin{tabular}{lllll}
\hline & NP 010 & NP 030 & NTR 729HF & RO \\
\hline $\mathrm{Ca}^{2+}$ & $12 \pm 4$ & $20 \pm 5$ & $62 \pm 7$ & $99 \pm 1$ \\
$\mathrm{Mg}^{2+}$ & $16 \pm 5$ & $22 \pm 2$ & $62 \pm 11$ & $98 \pm 1$ \\
$\mathrm{NO}_{3}{ }^{2-}$ & $\mathrm{Nil}$ & $18 \pm 5$ & $<5$ & 88 \\
$\mathrm{SO}_{4}{ }^{2-}$ & $41 \pm 6$ & $43 \pm 12$ & $99 \pm 1$ & $>99$ \\
$\mathrm{Na}^{+}$ & $\mathrm{Nil}$ & $\mathrm{Nil}$ & 19 & $96 \pm 1$ \\
$\mathrm{Cl}^{-}$ & $4 \pm 1$ & $5 \pm 1$ & $11 \pm 1$ & $92 \pm 1$ \\
DOC & $76 \pm 3$ & $84 \pm 2$ & $95 \pm 2$ & $>99$ \\
\hline
\end{tabular}


Table 4. The removal (\%) of PPCPs by NF and RO membranes from BTSE

\begin{tabular}{|c|c|c|c|c|c|c|c|c|}
\hline \multirow{2}{*}{ PPCPs } & \multirow{2}{*}{ MW } & \multirow{2}{*}{$\begin{array}{c}\mathrm{pKa} \\
(\mathrm{pH} 7)\end{array}$} & \multirow{2}{*}{$\begin{array}{c}\log \mathrm{P}^{\mathrm{a}} \\
\text { (Octonol- } \\
\text { water) } \\
\text { (pH 7) }\end{array}$} & \multirow{2}{*}{$\begin{array}{l}\text { PPCPs in } \\
\text { Feed water } \\
\text { ng/L }\end{array}$} & \multicolumn{4}{|c|}{$\begin{array}{c}\text { Removal \% } \\
\text { (effluent level ng/L) }\end{array}$} \\
\hline & & & & & NP010 & NP030 & $\begin{array}{c}\text { NTR } \\
729 H F\end{array}$ & $\mathrm{RO}$ \\
\hline $\begin{array}{l}\text { Atenolol } \\
\text { (Beta-blocker) }\end{array}$ & 266 & $9.6^{b}$ & 0.16 & $77.6-220$ & $<5(76)$ & 58 (33) & $75.5(20)$ & $98(<5)$ \\
\hline $\begin{array}{l}\text { Sulfamethoxazole } \\
\text { (antibiotic) }\end{array}$ & 253 & $2.1^{\mathrm{C}} ;<2^{\mathrm{C}}$ & 0.89 & $109-174$ & $27(80)$ & $50(55)$ & $98(<5)$ & $97(<5)$ \\
\hline $\begin{array}{l}\text { Caffeine } \\
\text { (therapeutics) }\end{array}$ & 194 & $10.4^{\mathrm{d}}$ & -0.07 & $88-675$ & Nil (646) & Nil (631) & 35 (57) & 97 (39) \\
\hline $\begin{array}{l}\text { Trimethoprim (anti- } \\
\text { biotic ) }\end{array}$ & 290 & $6.6-7.2^{\mathrm{e}}$ & 0.91 & $146-229$ & 8 (146) & $8(146)$ & 79 (31) & $98(<5)$ \\
\hline $\begin{array}{l}\text { Carbamazepine } \\
\text { (anti-seizure) }\end{array}$ & 236 & $<2^{\mathrm{C}}$ & 2.45 & $362-434$ & $<5(345)$ & $<5(352)$ & $87(50)$ & $98(<5)$ \\
\hline $\begin{array}{l}\text { Fluoxetine } \\
\text { (anti-depressive } \\
\text { agent) }\end{array}$ & 309 & $10.1^{\mathrm{e}}$ & 4.05 & $<5-20$ & $13(11)$ & $68(<5)$ & $N D^{f}$ & $\mathrm{ND}^{\mathrm{t}}$ \\
\hline $\begin{array}{l}\text { Amtriptyline } \\
\text { (analgesics) }\end{array}$ & 277 & $9.4^{\mathrm{a}}$ & 4.92 & $11-37$ & $52(7)$ & $74(<5)$ & $64(<5)$ & $89(<5)$ \\
\hline $\begin{array}{l}\text { Primidone } \\
\text { (anticonvulsant) }\end{array}$ & 218 & - & 0.91 & $11-26$ & 23 (17) & 39 (14) & $85(<5)$ & $62(<5)$ \\
\hline $\begin{array}{l}\text { Verapamil } \\
\text { (therapeutics) }\end{array}$ & 455 & $8.92^{\mathrm{a}}$ & 3.79 & $9-28$ & $13(8)$ & $57(<5)$ & $66(<5)$ & $86(<5)$ \\
\hline $\begin{array}{l}\text { Diclofenac (anti- } \\
\text { inflammatory) }\end{array}$ & 296 & $4.1-4.2^{\mathrm{e}}$ & 4.51 & $57-131$ & $16(71)$ & $29(60)$ & $93(<5)$ & $97(<5)$ \\
\hline $\begin{array}{l}\text { Naproxen } \\
\text { (analgesic) }\end{array}$ & 230 & $4.2^{\mathrm{e}}$ & 3.18 & 68.8-211 & $32(47)$ & $54(32)$ & $95(<5)$ & $98(<5)$ \\
\hline $\begin{array}{l}\text { Gemfibrozil } \\
\text { (therapeutics) }\end{array}$ & 250 & $4.7^{c}$ & 4.77 & $31-430$ & $16(122)$ & 20 (117) & $72(9)$ & $99(<5)$ \\
\hline
\end{tabular}

${ }^{a}$ MW and Log P values were obtained from U.S National medicine library. Online http://chem.sis.nlm.nih.gov/chemidplus/

${ }^{\mathrm{b}}$ Hapeshi et al. [31]

${ }^{\mathrm{c}}$ Westerhoff et al. [32]

${ }^{\mathrm{d}}$ Yang et al. [33]

e Serrano et al. [34]

${ }^{\mathrm{f}}$ PPCPs not detected in feed water 
Table 5. Different blending ratios of NF permeate and RO permeate required to obtain product water suitable for irrigation.

\begin{tabular}{|c|c|c|c|c|c|c|c|c|c|c|c|c|}
\hline \multirow[t]{2}{*}{ Parameters } & $\begin{array}{c}\text { NF } \\
\text { permeate } \\
\text { proportion }\end{array}$ & 0.0 & 0.1 & 0.2 & 0.3 & 0.4 & 0.5 & 0.6 & 0.7 & 0.8 & 0.9 & 1.0 \\
\hline & $\begin{array}{c}\text { RO } \\
\text { permeate } \\
\text { proportion }\end{array}$ & 1.0 & 0.9 & 0.8 & 0.7 & 0.6 & 0.5 & 0.4 & 0.3 & 0.2 & 0.1 & 0.0 \\
\hline $\begin{array}{l}\text { SAR } \\
\end{array}$ & & 3 & 4 & 5 & 6 & 7 & 8 & 10 & 11 & 12 & 13 & 14 \\
\hline $\mathrm{Ca}$ & & 0.3 & 2 & 3 & 4 & 5 & 7 & 8 & 9 & 10 & 12 & 13 \\
\hline $\mathrm{Mg}$ & & 0.1 & 1 & 2 & 3 & 4 & 5 & 5 & 6 & 7 & 8 & 9 \\
\hline $\mathrm{K}$ & & 0.7 & 2 & 3 & 4 & 5 & 6 & 7 & 9 & 10 & 11 & 12 \\
\hline $\mathrm{Na}$ & & 4 & 15 & 26 & 36 & 47 & 57 & 68 & 79 & 89 & 100 & 111 \\
\hline $\mathrm{Cl}$ & & 16 & 35 & 53 & 72 & 90 & 109 & 128 & 146 & 165 & 183 & 202 \\
\hline $\mathrm{S}$ & & 0.2 & 0.3 & 0.3 & 0.4 & 0.4 & 0.5 & 0.6 & 0.6 & 0.7 & 0.7 & 0.8 \\
\hline $\mathrm{NO}_{3}{ }^{-} \mathrm{N}$ & & 2 & 3 & 4 & 5 & 6 & 7 & 8 & 9 & 10 & 11 & 12 \\
\hline B & & $<0.1$ & $<0.1$ & $<0.1$ & $<0.1$ & $<0.1$ & $<0.1$ & $<0.1$ & $<0.1$ & $<0.1$ & $<0.1$ & $<0.1$ \\
\hline
\end{tabular}




\section{List of Figures}

Fig. 1. Schematic diagram of NF and RO filtration units used

Fig. 2. Schematic diagram of NF/RO membrane operations: (a) single step NF or RO

(Treatment train 1) (b) two steps NF and RO in series (Treatment train 2)

Fig. 3. Effect of operation time on the concentration of inorganic solutes and DOC in NF permeates.

Fig. 4. Membrane autopsy for organic depositions on RO membranes with and without NF as pre-treatment (LMW, low molecular weight) 


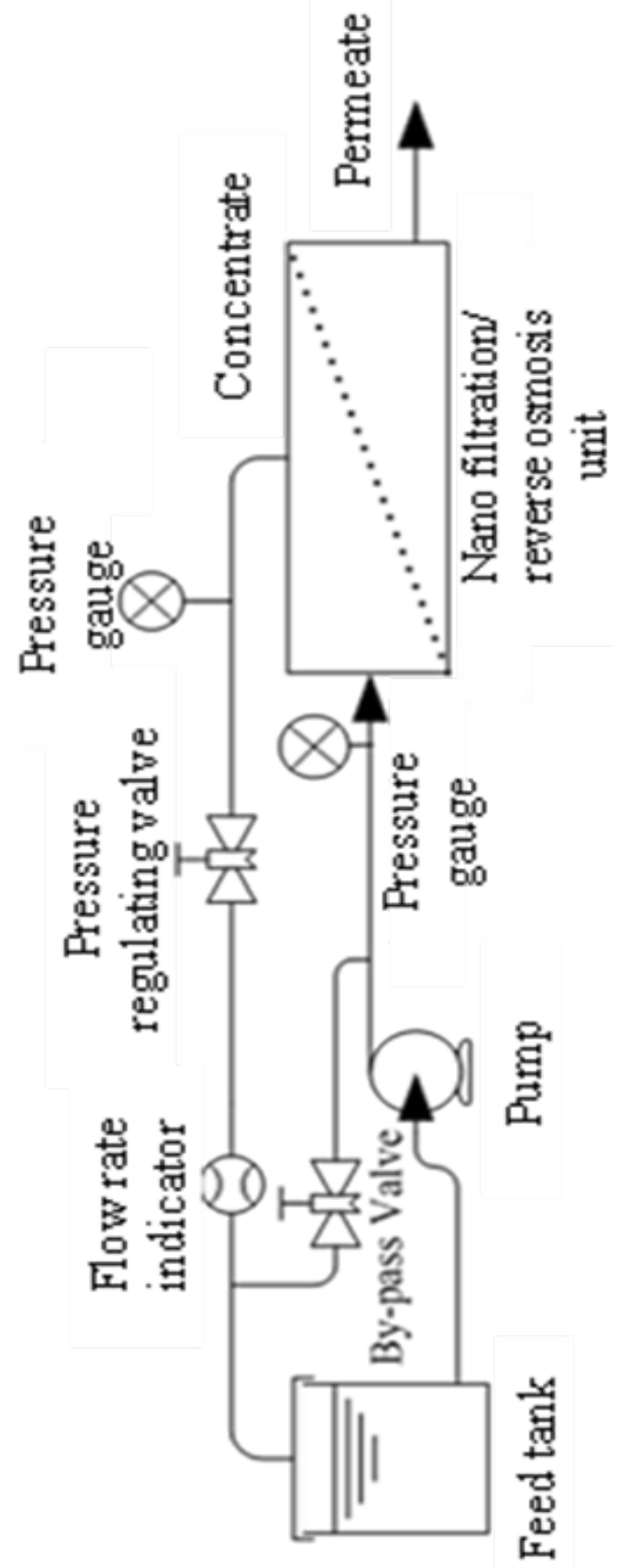

Fig. 1 


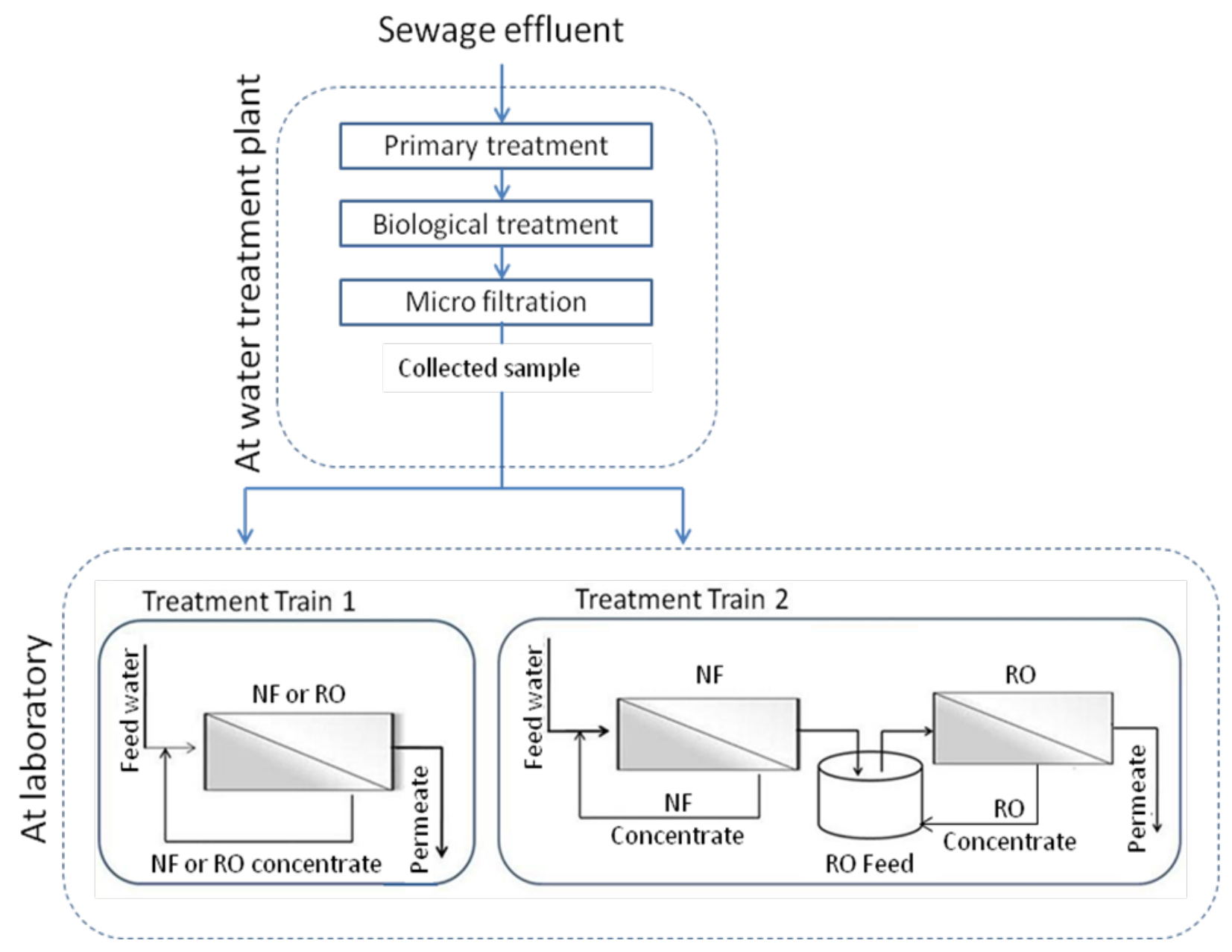

Fig. 2 


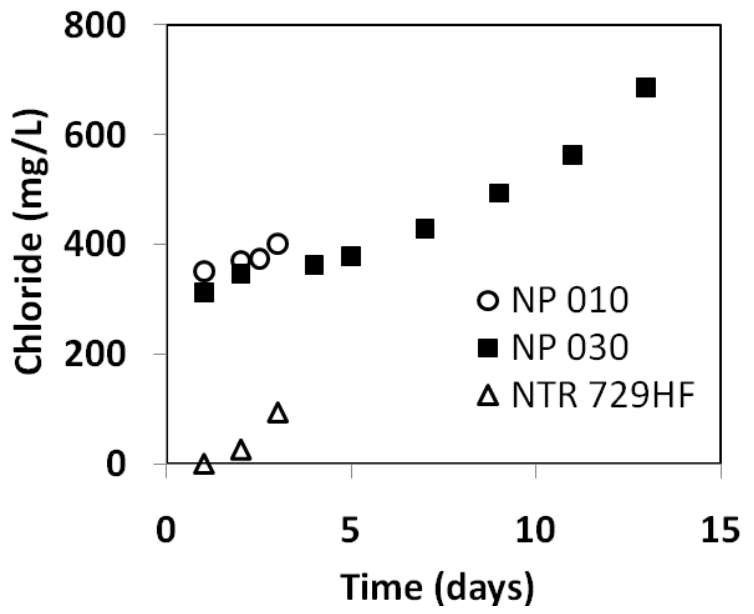

(a)

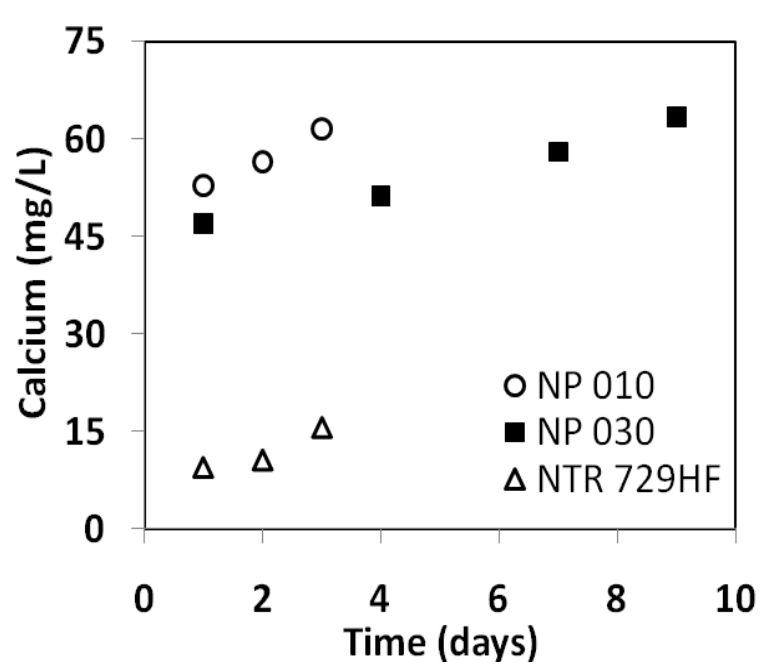

(c)

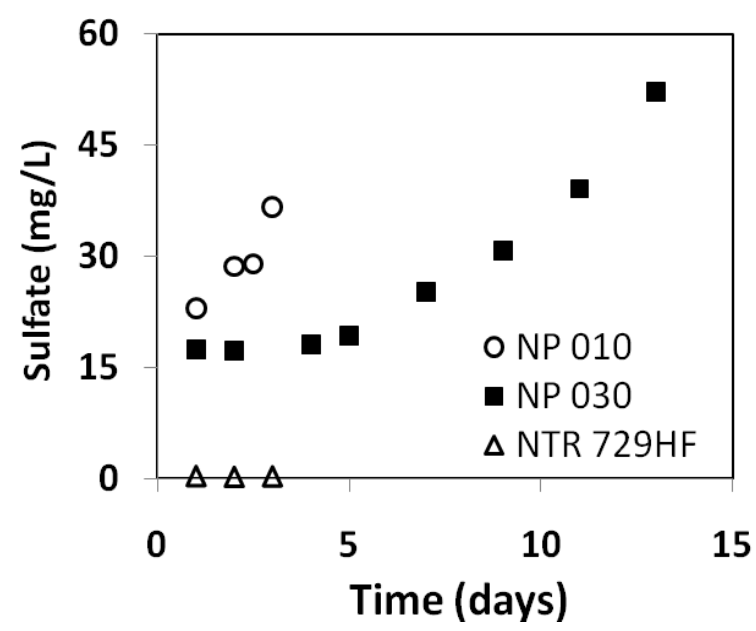

(b)

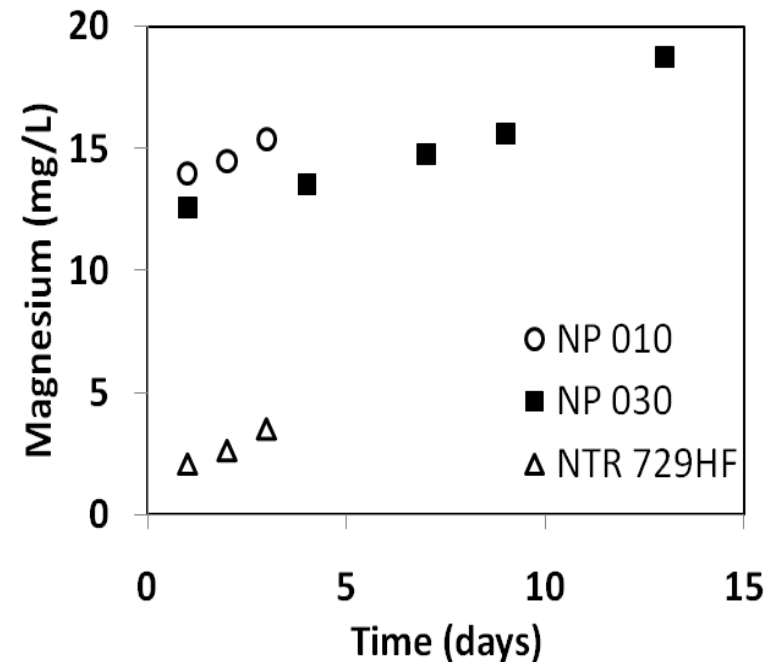

(d)

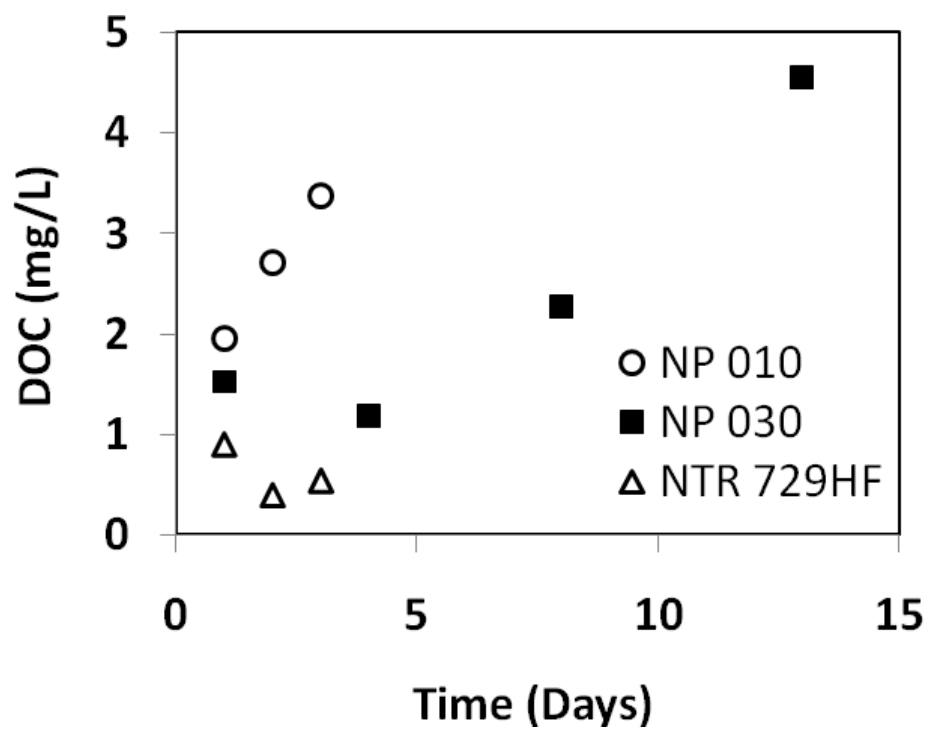

(e)

Fig. 3 


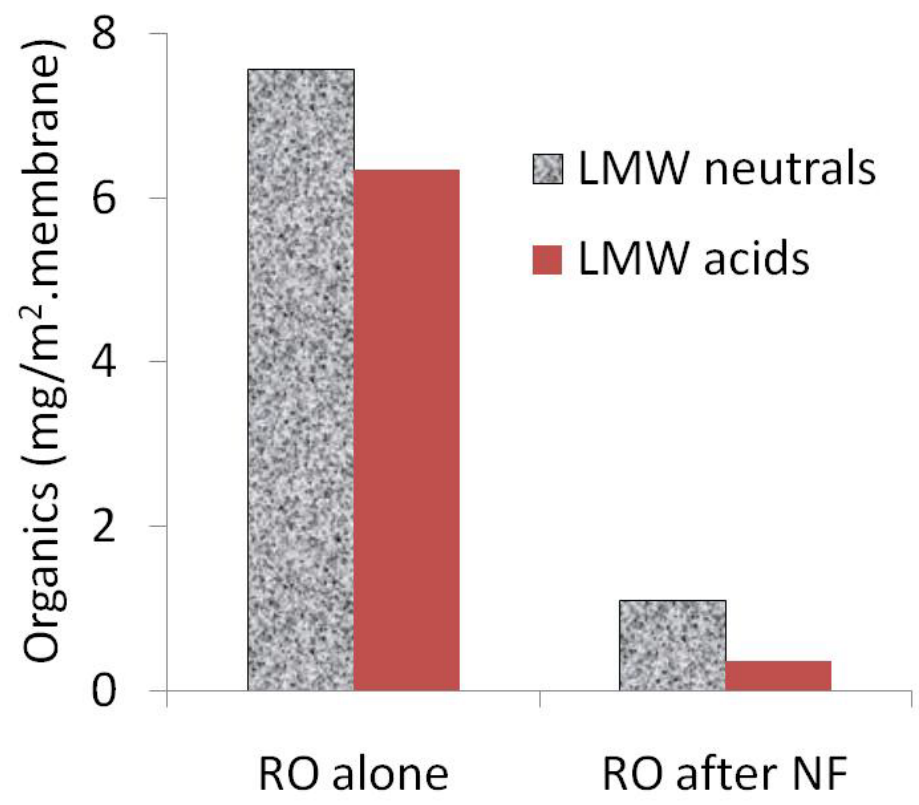

Fig. 4 